\title{
Prototype Smart Home With Voice Recognition Berbasis Arduino Uno
}

\section{Muhammad Siddik Hasibuan}

Universitas Islam Negeri Sumatera Utara, Medan, Indonesia

Email : muhammadsiddik@uinsu.ac.id

\begin{abstract}
Abstrak
Smart Home atau rumah pintar adalah suatu sistem yang dapat mempermudah dan menambah kenyaman si pemilik rumah khususnya dalam hal mengontrol peralatan elektronik didalam rumah sehingga dapat mengurangi pemborosan dalam pemakaian peralatan elektronik dan memberikan keamanan kepada si pemilik rumah sehingga terhindar dari korsleting arus listrik apabila tangan si pemilik basah. Tulisan ini membahas tentang perancangan sistem pada smart home yang dapat mematikan atau menghidupkan peralatan elektronik dalam hal ini hanya sebatas pada lampu.
\end{abstract}

Kata Kunci : Rumah Pintar, Easy VR, Arduino Uno, Pengenalan Suaran

\section{Abstract}

Smart home or smart home is a system that can facilitate and increase the comfort of the homeowner specifically in terms of controlling electronic equipment in the house so that it can reduce waste in the use of electronic equipment and provide security to the homeowner so that the electrical short circuit is used the owner is wet. This paper discusses the design of systems in smart homes that can activate or activate electronic equipment in this case only to the lights.

Keywords : Smart home, Easy VR, Arduino Uno, Voice Recognition

\section{PENDAHULUAN}

Karena pesat nya perkembangan teknologi saat ini membawa dampak positif pada kehidupan manusia, contoh perkembangan teknologi saat ini adalah teknologi perintah suara. Yaitu kondisi yang memungkinkan kita untuk berbicara kepada alat elektronik di dalam rumah kita. Dalam hal ini suara manusia dapat di olah untuk di konversi dan dapat di mengerti oleh sistem sehingga perintah yang terucap dapat di respon oleh alat yang dikendalikan. Pengolahan suara digital dikontrol menggunakan aplikasi yang dapat mengenali adanya perintah suara yang di deteksi (Speech Recognition). Alat ini bekerja dengan menangkap suara si pengguna yang di ubah menjadi digital print kemudian akan di cocokan informasi masukan yang sudah berupa digital print tersebut dengan database suara yang ada. Salah satu alat yang dapat diaplikasikan dalam kehidupan sehari-hari adalah sistem rumah pintar (smart home)Terhulin (2015).

Pada tulisan kali ini penulis akan membahasa cara perancangan suatu sistem pada smart home yang menggunakan perintah suara sebagai kata kuncinya yang akan di proses menggunakan microphone pada module easy vr. Ketika suara yang di ucapkan sesuai dengan kata kunci suara yang tersimpan pada saat kita rekam pertama kali, perangkat akan merespon dan peralatan elektronik akan menyala atau untuk dimatikan. 


\section{LANDASAN TEORI}

\section{a. Easy $V R$}

Easy vr merupakan module voice recognition multi fungsi dan dapat digunakan pada banyak aplikasi pengontrolan yang membutuhkan pendeteksian bukan hanya sebatas suara melainkan percakapan. Modul ini dapat digabungkan dengan board mikrokontroler Arduino (Akhmad, 2016).

\section{b. Arduino UNO}

Merupakan flatform dari physical computingdan bersifat open source. Arduino digunakan untuk menghubungkan modul easy vrdan untuk melakukan perekaman suara atau kata kunci (Hasan dan Hasibuan, 2017).

\section{c. Relay}

Relay merupakan saklar elektronik yang dalam hal ini untuk memutuskan dan menghubungkan arus listrik.

\section{d. SoftwareEasy Vr Commander}

Software ini merupakan aplikasi bawaan pada module easy $v r$ untuk melakukan pelatihan atau perekaman suara yang nantinya akan digunakan sebagai kata kunci.

\section{Metode Penelitian}

\section{a. Blok Diagram}

Blok diagram dari prototype smart home menggunakan pengenalan suara dengan easy vr berbasis arduino uno dapat dilihat dari gambar berikut :

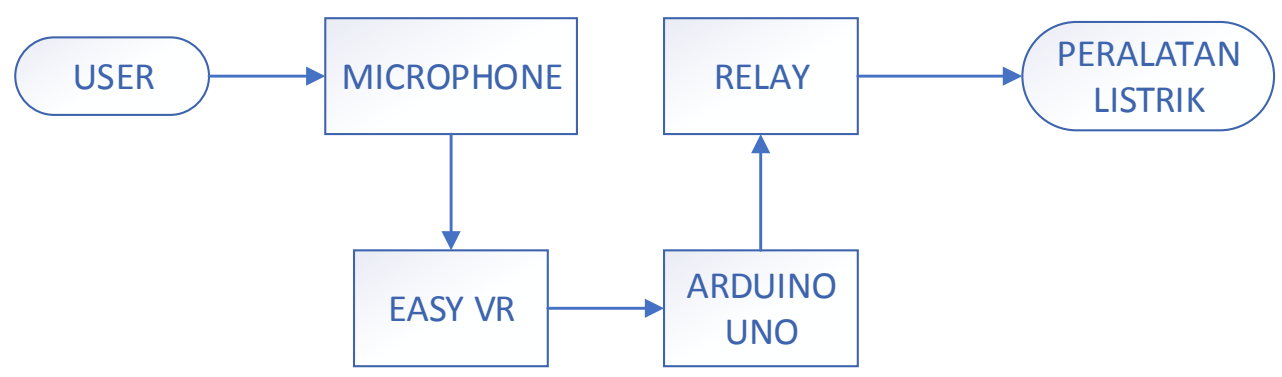

Gambar 1.Blok diagram dari prototype smart home dengan easy vr berbasis arduino

Penjelasan blok diagram diatas adalah sebagai berikut.

1. User, mengontrol smarthome menggunakan suara dengan menggunakan microphone pada easy voice recognition.

2. Suara, berfungsi sebagai input yang memicu easy vr untuk mengirimkan data ke dalam arduino dalam mengontrol smarthome.

3. Easy VR, berfungsi sebagai modul voice recognition yang menyimpan dan menjalankan data input suara sesuai dengan perintah yang dimasukkan ke dalam program. 
4. Arduino Uno, berfungsi sebagai pengolah data yang didapatkan dari Easy VR untuk menjalankan relay.

5. Relay, berfungsi sebagai penggerak kontak saklar dimana pada alat ini berfungsi untuk menghidupkan atau mematikan lampu

\section{b. Desain Sistem (Flowchart)}

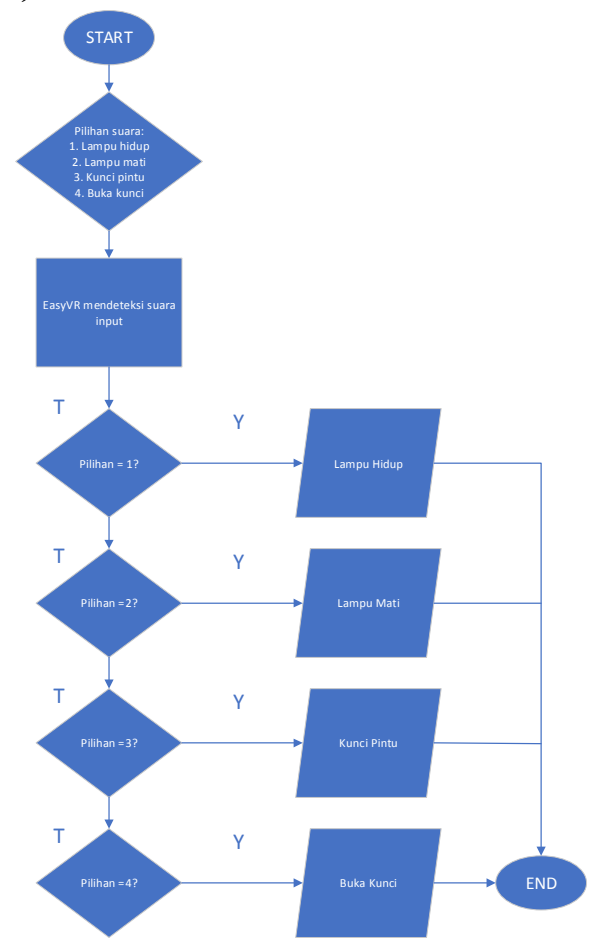

Gambar 2.2 Flowchart Prototype Smart Home with Voice Recognition

\section{c. Desain Rangkaian}

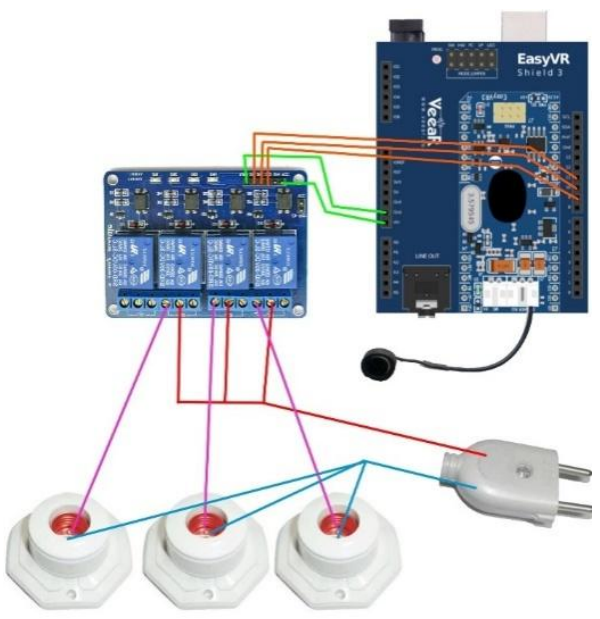

Gambar 2.Desain rangkaian pada alat

\section{d. Perancangan Voice Recognition}

Perancangan ini bertujuan untuk mengambil contoh suara yang akan disimpan kedalam module EasyVR. Proses perekaman suara dilakukan menggunakan PC dengan software dari EasyVR yaitu EasyVRcommander. 
Terdapat beberapa perintah yang akan digunakan untuk mendapatkan contoh suara adalah sebagai berikut :

1. Langkah pertama adalah dengan menambahkan command kedalam group melalui perintah "add command" yang terdapat didalam software tersebut.

2. Lalu pilih perintah "train command" untuk melalukan perekaman suara sebagai contoh suara yang akan digunakan.

3. Rekam commandatau suara dengan microphone pada EasyVR.

4. Perintah "test group" berguna untuk mengecek apakah hasil sampling suara mampu digunakan dengan cara memasukkan input suara melalui sensor microphone.

5. Generate code berguna untuk menunjukkan code dalam bahasa $\mathrm{C}$ untuk memudahkan pemograman pada perancangan software.

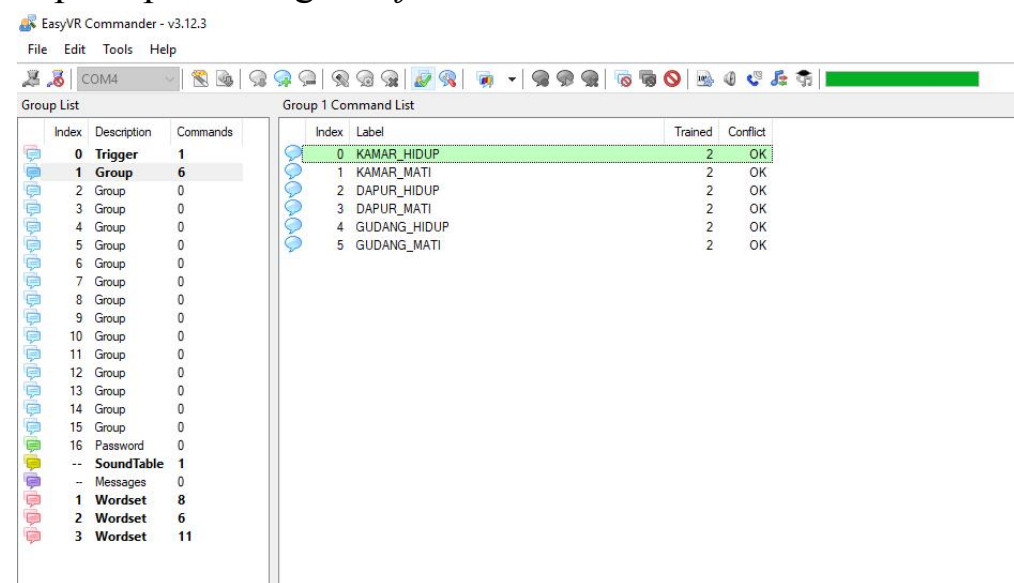

Gambar 3 Contoh data suara yang telah di rekam

Dari gambar diatas menunjukan data suara yang sudah di ambil terdapat pada group 1. Berikut ini adalah keterangan dari hasil perekaman suara menurut kunci yang diucapkan :

1. KAMAR_HIDUP : Berisi contoh suara dengan kata "kamar hidup" yang berfungsi sebagai password untuk menghidupkan lampu.

2. KAMAR_MATI : Berisi contoh suara dengan kata "kamar mati" yang berfungsi sebagai password untuk mematikan lampu.

3. DAPUR_HIDUP : Berisi contoh suara dengan kata "dapur hidup" yang berfungsi sebagai password untuk menghidupkan lampu dapur.

4. DAPUR_MATI : Berisi contoh password dengan kata "dapur mati” yang berfungsi sebagai password untuk mematikan lampu dapur.

5. GUDANG_HIDUP : Berisi contoh password dengan kata "gudang hidup" yang berfungsi sebagai password untuk menghidupkan lampu gudang.

6. GUDANG_MATI : Berisi contoh password dengan kata "gudang mati" yang berfungsi sebagai password untuk mematikan lampu gudang.

\section{Hasil dan Pembahasan}

Setelah melakukan analisa, merancang serta membangun dan sudah melakukan pengujian terhadap Prototype Smart Home With Voice Recognition, maka penulis mendapatkan hasil bahwa pada saat melakukan pengenalan suara oleh Module EasyVR, alat dapat mengenali suara dengan baik apabila menggunakan nada suara yang sama pada saat 
melakukan train voicedan jika menggunakan nada suara dari orang lain, alat dapat bekerja apabila menggunakan nada suara yang sama dengan yang terdapat pada rekaman.

Ketika alat dapat mengenali suara dengan baik, alat mampu menghidupkan peratalan listrik meskipun dari jarak yang jauh sekalipun. Apabisa suara yang di ucapkan tidak jelas atau dengan nada yang berbeda meskipun dengan jarak yang dekat, alat tidak akan merespon atau peralatan listrik pun tidak dapat menyala.

Jika terjadi kegagalan pada proses voice recognition, itu disebabkan karena saat pengucapan kata kunci mungkin nada yang di ucapkan berbeda atau suara terlalu pelan sehingga tidak dapat dikenali oleh alat tersebut.

\section{a. Pembahasan}

Setelah melakukan pengujian terhadap penelitian ini, maka dibagian ini akan dibahas secara rinci seluruh hasil yang telah diperoleh pada saat melakukan pengujian. Adapun yang akan dibahas pada bagian ini meliputi proses kerja dari alat, proses pengujian alat, dan pengimplementasian alat.

\section{Cara Kerja Alat}

Cara kerja dari alat ini adalah pengguna melakukan pengucapan kata kunci sesuai dengan alat - alat listrik yang akan dinyalakan atau dimatikan, dalam hal ini terbatas hanya lampu ke arah microphone. Ketika suara yang diucapkan terekam oleh microphone, maka suara tersebut akan langsung diproses oleh modul $E A S Y V R$, apakah suara yang terekam sama dengan kata kunci yang telah terekam di easy $v r$. Ketika suara yang kita ucapkan sama dengan kata kunci yang ada di easy vr, maka perinta akan langsung diproses oleh arduino, kemudian arduino akan mengaktifkan relay yang telah dipasangn pada alat untuk melakukan perintah sesuai dengan perintah yang diucapkan pengguna sebelumnya. Apakah menyalakan lampu ataupun mematikannya.

Namun ketika perintah yang kita ucapkan di microphone tidak sama dengan kata kunci yang telah terekam di dalam modul easy vr, maka alat ini tidak akan melakukan apapun, dengan kata lain tidak berfungsi. Maka kita diharuskan melakukan pengucapan ulang perintah yang kita inginkan sesuain dengan kata kunci yang terekam di dalam modul easy vr dan dengan nada yang sama.

\section{Pengujian Alat/interface pada aplikasi EasyVR Commander}

Proses pengujian alat dilakukan dengan aplikasi EasyVR Commander, dengan cara penulis mengucapkan ulang kata- kata kunci yang telah diatur, sebagai indikator alat untuk melakukan perintah berdasarkan kecocokan antara suara yang terekam dengan kata kunci yang telah direkam sebagai indikator. Dan yang dihasilkan adalah alat mampu bekerja sesuai harapan. Alat mampu menghidupkan lampu kamar dengan kata kunci "KAMAR_HIDUP" kemudian mematikannya dengan kata kunci "KAMAR_MATI". Kemudian alat juga mampu menyalakan lampu bagian dapur dengan kata kunci "DAPUR_HIDUP", dan mematikannya kembali dengan kata kunci "DAPUR_MATI". Yang terakhir alat mampu menyalakan lampu gudang dengan mengucapkan kata kunci "GUDANG_HIDUP", kemudian untuk mematikannya dengan mengucapkan kata kunci "GUDANG_MATI". Semua perintah perintah tersebut dapat dijalankan oleh alat ini hanya jika suara yang direkam tersebut terekam dengan jelas dan dengan nada suara yang sama. Dalam hal ini alat untuk merekam 
suara dilakukan oleh microphone. Adapun hasil dari penguian alat ini lebih jelas dapat dilihat seperti gambar berikut.

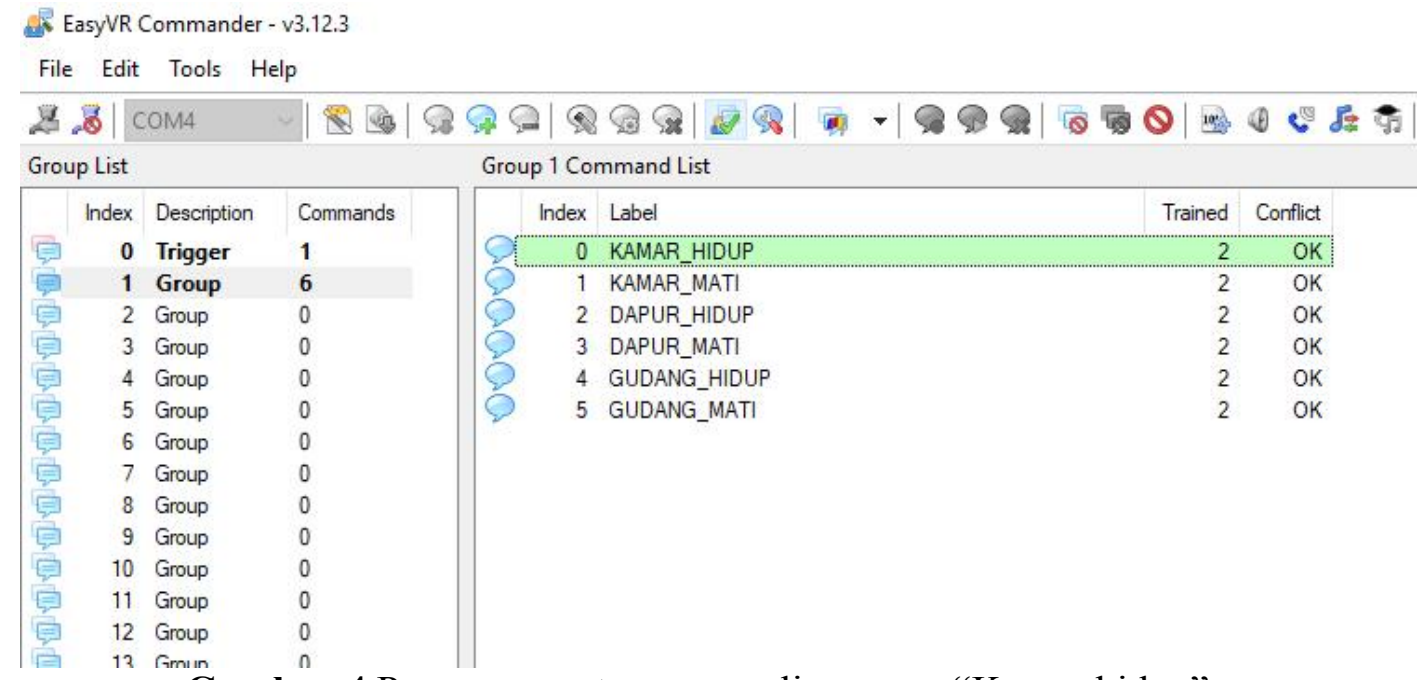

Gambar 4.Proses pengetesan sampling suara "Kamar hidup"

Sumber : Penulis (2018)

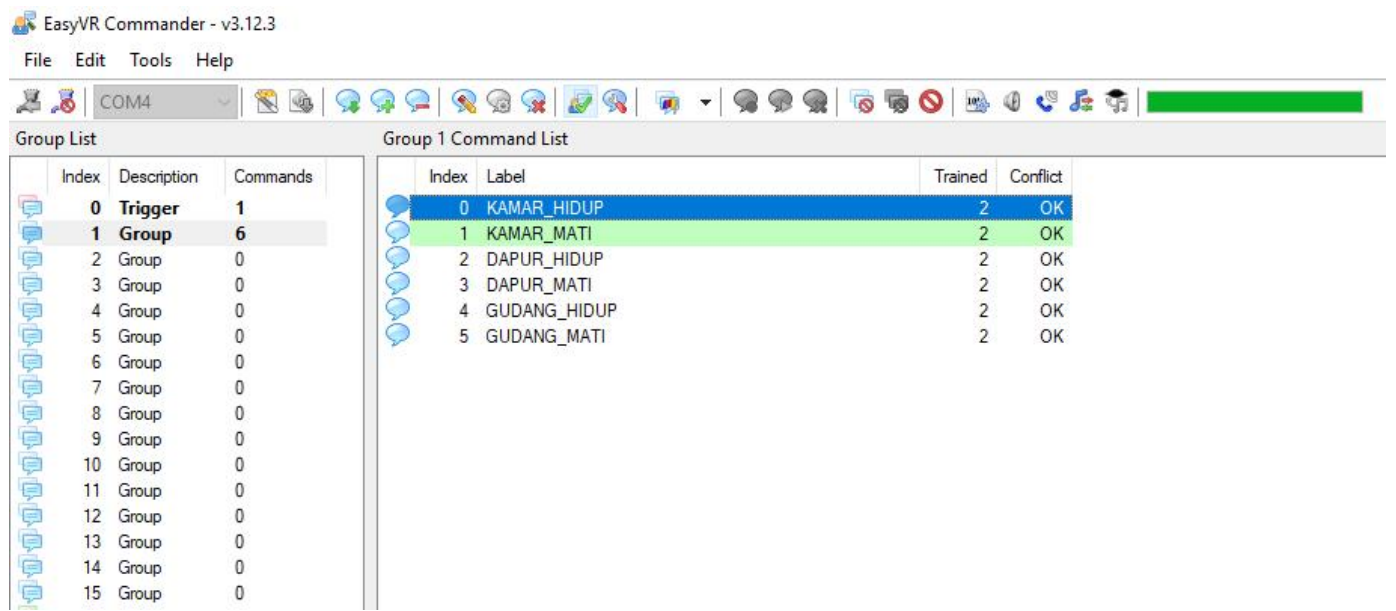

Gambar 5.Proses pengetesan sampling suara "Kamar mati"

Sumber : Penulis (2018)

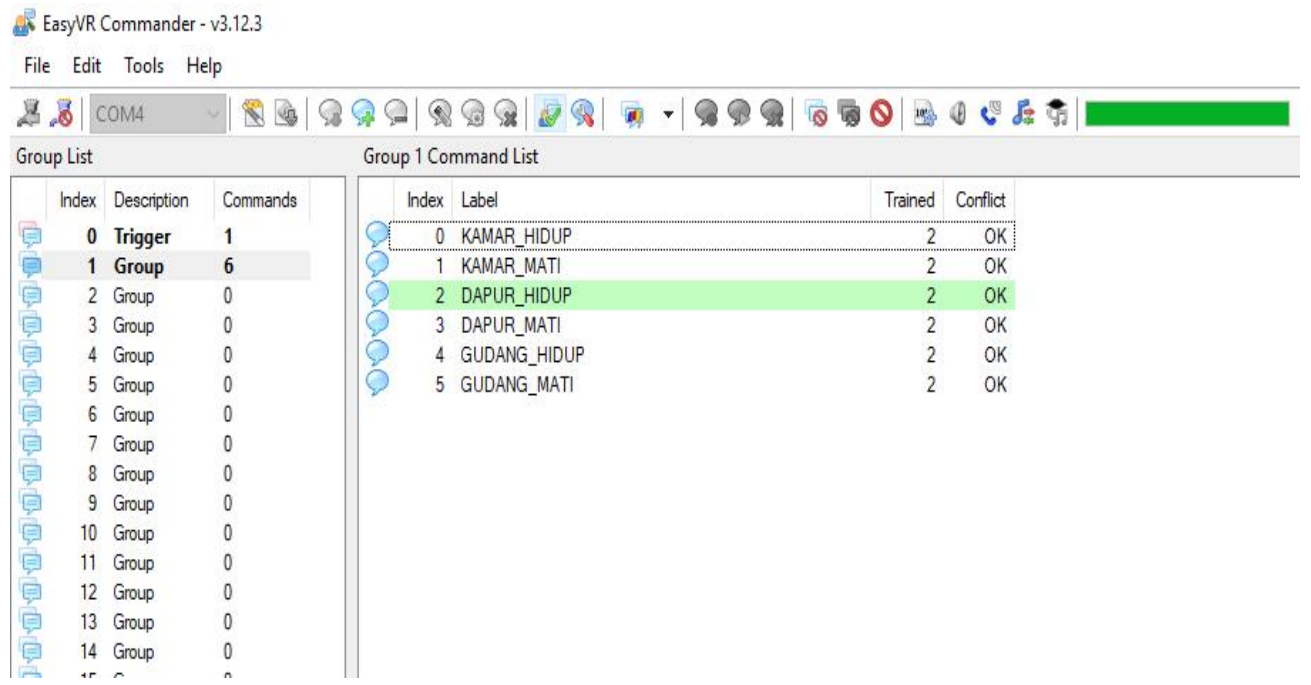

Gambar 6.Proses pengetesan sampling suara "Dapur hidup" 
Sumber : Penulis (2018)

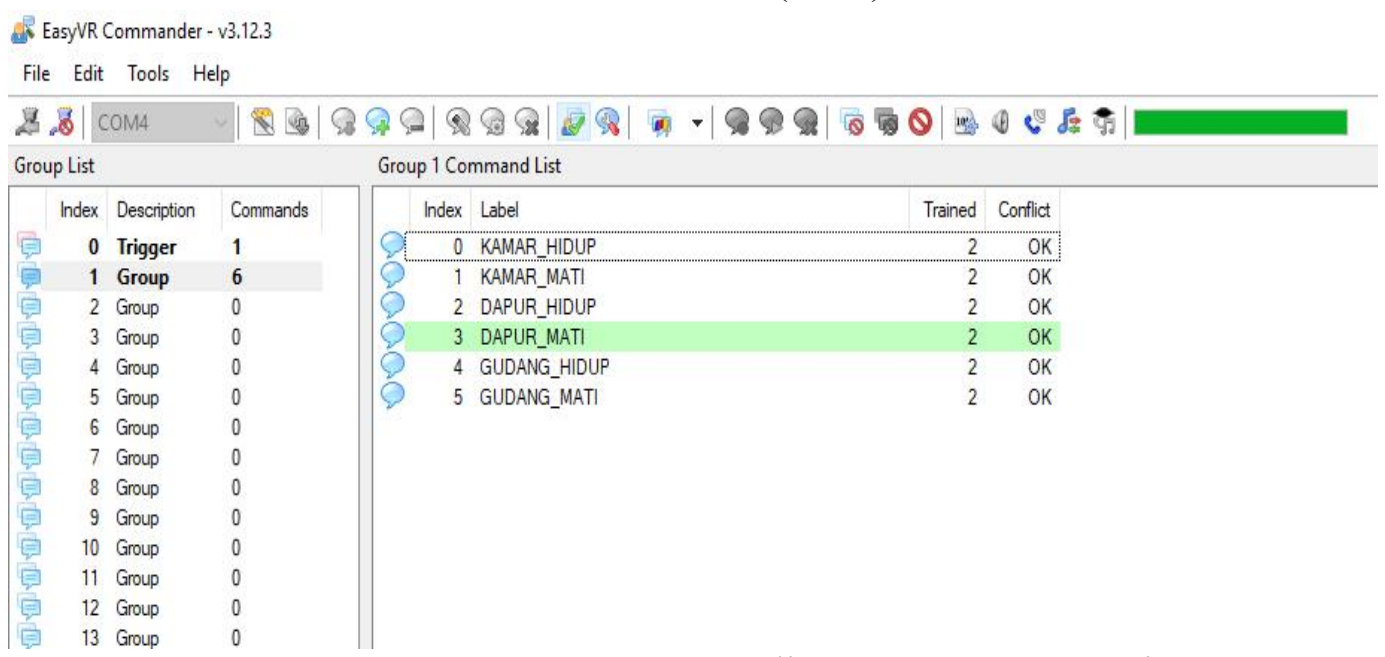

Gambar 7.Proses pengetesan sampling suara "Dapur mati"

Sumber : Penulis (2018)

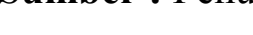

Gambar 8.Proses pengetesan sampling suara "Gudang hidup"

Sumber : Penulis (2018)

ais EasyVR Commander - v3.12.3

File Edit Tools Help

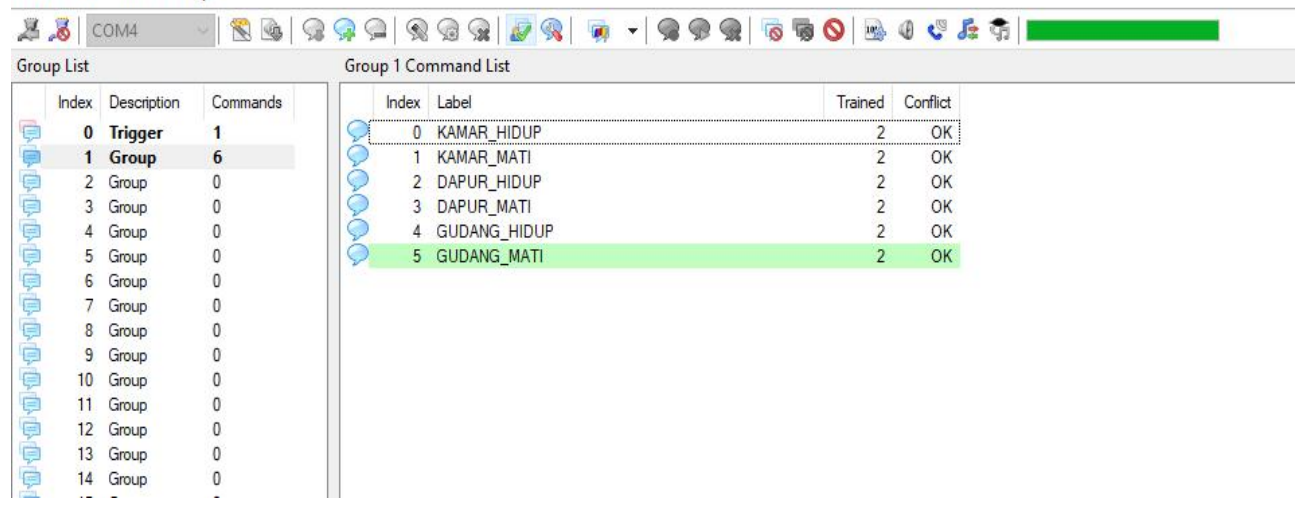

Gambar 9.Proses pengetesan sampling suara "Gudang mati"

Sumber : Penulis (2018) 


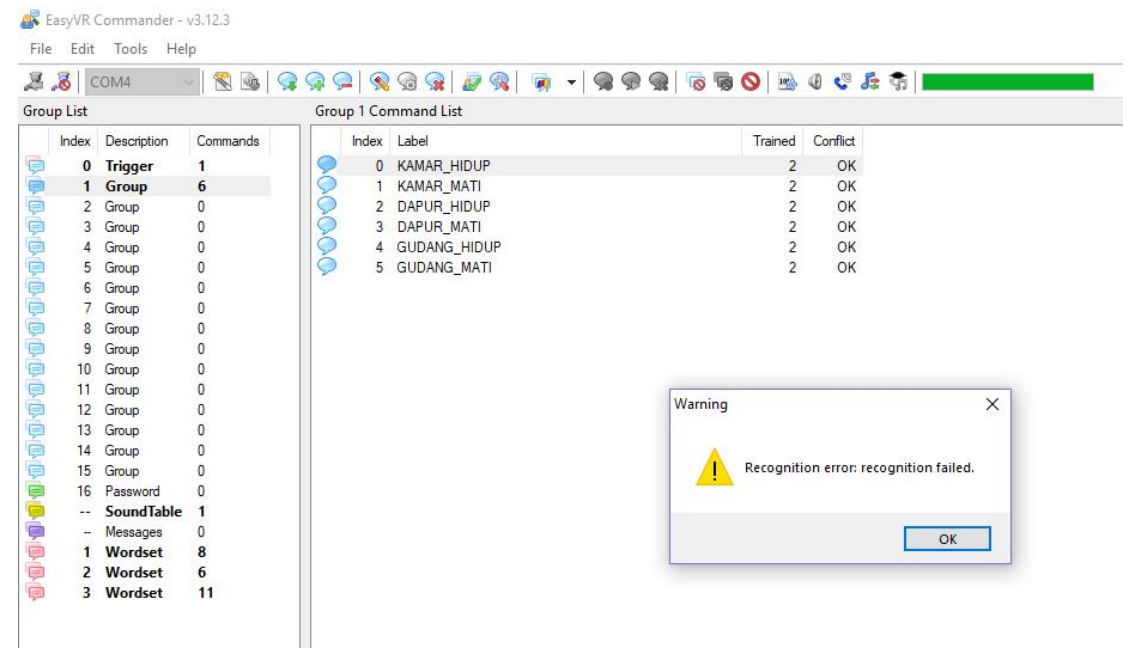

Gambar 10. Proses pengetesan dengan suara/nada yang tidak sesuai dengan rekaman saat awal Sumber : Penulis (2018)

\section{IMPLEMENTASI}

Dalam penelitian kali ini penulis membuat alat dalam bentuk prototype. Sehingga alat ini di uji di rumah yang berbentuk prototype rumah. Namun untuk mengiplementasikan dalam situasi yang sebenarnya alat ini tidak membutuhkan perombakan atau perubahan yang signifikan, karena meskipun alat ini dibuat dalam bentuk prototype, alat ini sudah bisa langsung diterapkan dalam situasi real (non prototype). Hanya saja perlu penmbahan ukuran kabel dari ukuran sekarang menjadi ukuran yang lebih panjang sesuai dengan kebutuhannya.

\section{KESIMPULAN}

Berdasarkan hasil pengujian yang sudah dilakukan telah didapatkan kesimpulan sebagai berikut :

1. Alat akan dapat bekerja dengan baik dalam memproses suara apabila menggunakan sampling suara yang sama ketika melakukan proses perekaman suara.

2. Module EasyVR memiliki tingkat keberhasilan yang baik dalam proses pengenalan suara.

3. Alat ini mampu memberikan kenyamanan dan keamanan bagi si pemilik rumah dalam hal untuk menghidupkan lampu.

\section{SARAN}

Karena masih banyak nya kekurangan baik dalam tulisan atau pun rangkaian yang telah dibuat, adapun saran yang dapat diberikan dari hasil penelitian ini adalah sebagai berikut.

1. Mengganti interface untuk pengenalan suara tidak hanya terbatas pada microphone. Seperti menggunakan android untuk perekaman suara, sehingga meningkatkan efisiensi alat dalam hal proses pengenalan suara.

2. Menambah perangkat yang bisa dikendalikan melalui suara tidak hanya sebatas pada lampu saja. 


\section{DAFTAR PUSTAKA}

Akhmad, Wahyu Dani (Vol.7 No.1 Januari 2016) PERANCANGAN APLIKASI VOICE COMMAND RECOGNITION BERBASIS ANDROID DAN ARDUINO UNO

Terhulin,Putra Tambak (2015) PERANCANGAN SISTEM HOME AUTOMATION BERBASIS ARDUINO UNO

Hasan, L.M dan Hasibuan, M.S, SMART SYSTEM SENT GAS LEAK DETECTION MESSAGE BY USING (V O L 11 - I R S T C 2017 \& R E S P E X 201 7).Jojaps-politeknik port dickson, Malaysia

http://www.tokobuku.com. (Diakses tanggal 12 April 2018)

http://www.polinpdg.ac.id. (Diakses tanggal 19 April 2018)

http://www.veear.eu. (Diakses tanggal 19 April 2018)

https://teknik-elektronika.com/pengertian-relay-fungsi-relay.htm 1(Diakses tanggal 19 April 2018)

http://wiki.sunfounder.cc/index.php?title=4_Channel_5V_Relay_Module(Diakses tanggal 19 April 2018)

https://media.neliti.com/aplikasi-pengenalan-suara-sebagai-pengendali-peralatan-listrik-berbasisarduino-uno. (Diakses tanggal 22 April 2018) 